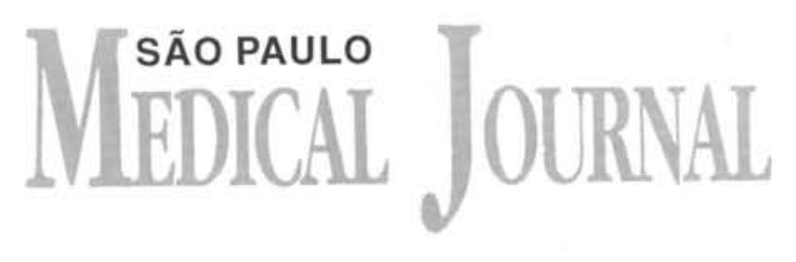

Gustavo Rubino de Azevedo Focchi, Manuel de Jesus Simōes, Edmund Chada Baracat, Geraldo Rodrigues de Lima,

Joaquim Evêncio Neto

\title{
Ultrastructural aspects of the remodeling process of the Corpus albicans in the recent postmenopausal period
}

\author{
Department of Obstetrics and Gynecology and Department of Morphology, \\ Escola Paulista de Medicina, Universidade Federal de São Paulo - São Paulo, Brazil
}

To study the cytophysiology of the corpus albicans in the recent postmenopausal period, the authors analyzed the ovarian ultrastructure of ten patients submitted to oophorectomy due to non-malignant gynecological diseases. Evidence of a remodeling process with connective tissue substitution of the corpora albicantia was observed. The remodeling process appears to depend on the activity of three essential cell types: the fibroblasts, which provide collagen synthesis; the macrophages, which phagocytize the flaky material; and the myofibroblasts, mainly located in the peripheral region of the corpora albicantia, which may have a retracting action on the remodeling site of the corpus albicans.

UNITERMS: Corpus albicans. Menopause. Ultrastructure. Cytophysiology. Remodeling process.

\section{INTRODUCTION}

I $n$ a study of the quantitative alterations of the corpora albicantia, JOEL \& FORAKER ${ }^{1}$ did not observe significant changes in the number of these structures, or in the ovarian area they occuppied before and after menopause. However, the corpora albicantia showed the presence of sclerosis, hyalinization and lack of fibroblastic activity after cessation of the menstrual cycles. ${ }^{2}$ Observations on the ultrastructural features of the corpora albicantia were made by $\operatorname{HAIDAR}^{3}$ who, after studying

\author{
Address for correspondence: \\ Edmund Chada Baracat \\ Disciplina de Ginecologia - Escola Paulista de Medicina \\ Universidade Federal de São Paulo \\ Rua Botucatu, 740 - Vila Clementino \\ São Paulo/SP - Brasil - CEP 04023-900
}

the ovaries of women suffering from premature ovarian failure, described corpora albicantia which consisted of a flaky material containing fibroblasts and macrophages, the latter mainly located in the peripheral portion of structure. In light of previous microscopy studies, it has been observed that, within the course of the postmenopausal period, there is an increase in the frequency of corpora albicantia containing few cells immersed in an eosinophilic mass. ${ }^{4}$ These findings may be related to the lower hormonal levels that characterize the postmenopausal period, and might contribute to the decrease of the remodeling process of the corpora albicantia, explaining the persistence of those morphological entities in the ovaries of postmenopausal women. Since a survey of the literature did not show studies on the cytophysiology of available corpora albicantia, in the present investigation we analyzed the ultrastructural features of the corpus albicans during the early postmenopausal period in order to determine how its remodeling process takes place. 


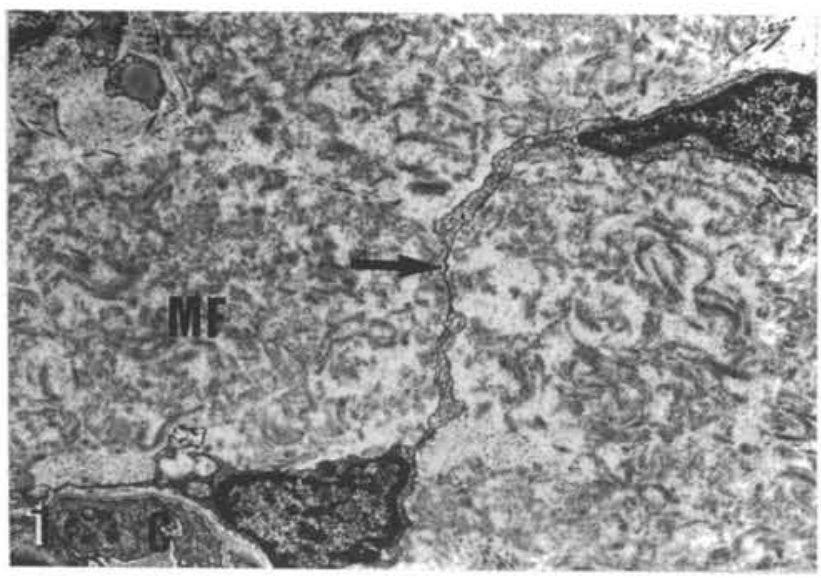

Figure 1 - Electronmicrograph showing the central region of a corpus albicans from a postmenopausal woman. Fibroblasts showing cytoplasmic prolongations (arrow) and intermixed with a flaky material (FM) are visible. A capillary (C) can also be seen in this figure $(1,600 \mathrm{X})$.

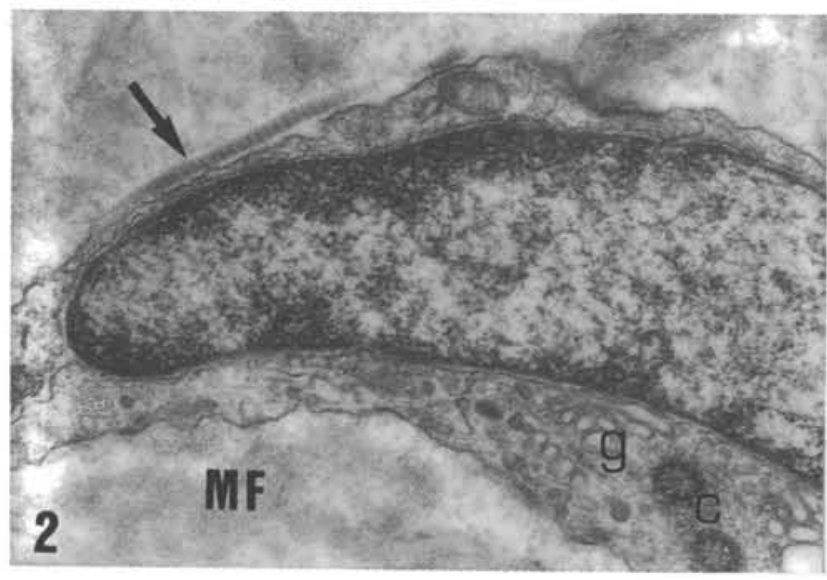

Figure 2 - Electronmicrograph showing a fibroblast located in the central region of the corpus albicans from a postmenopausal woman. Observe the presence of flaky material (FM) and collagen fibers (arrow). The cytoplasm contains clearly visible centrioles (C) and the Golgi apparatus (G) (20,700X).

\section{METHODS}

We utilized ovaries obtained from ten women in the early postmenopausal period (less than five years of menopausal time), who were submitted to oophorectomy due to non-malignant gynecological diseases. Fragments of the ovaries were fixed in 2 percent glutaraldehyde in $0.1 \mathrm{M}$ phosphate buffer, $\mathrm{pH} 7.2$, for 4 hours and then postfixated in 1 percent osmium tetroxyde for 1-2 hours. After immersion in 0.5 percent uranyl for 12 hours, the material was dehydrated in graded ethanols and then embedded in araldyte. Semi-thin sections were prepared for orientation. Silver- to light-thin sections were double stained with $1 \%$ uranyl acetate and lead citrate and examined using a Zeiss EM 9s-2 electron microscope.

\section{RESULTS}

Fibroblasts with eucromatinic-rich nuclei and several cytoplasmic prolongations, which maintained contact with adjacent cells, were observed inside the corpora albicantia (Fig. 1). These cells were surrounded with collagen fibers and were intermixed with large amounts of a flaky material (Fig. 2), forming a kind of cellular weave. Macrophages

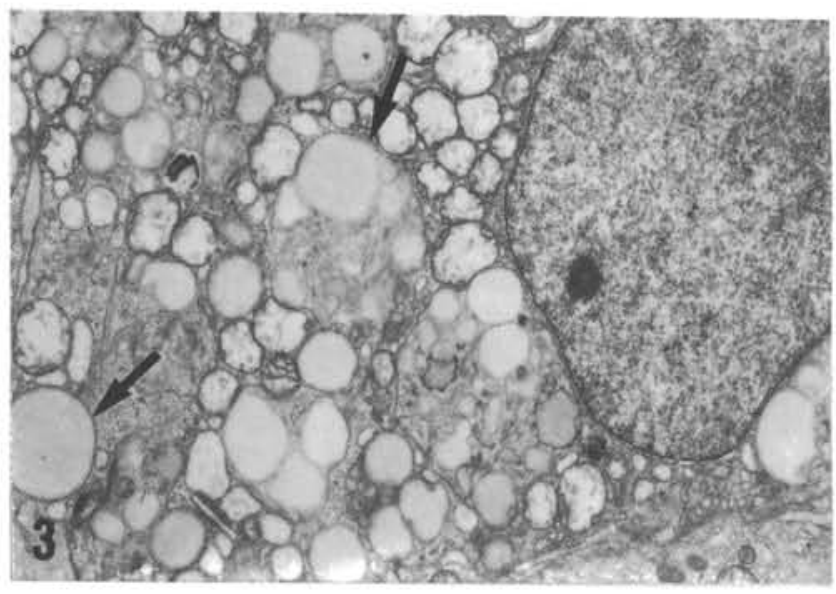

Figure 3 - Electronmicrograph showing part of a macrophage in the corpus albicans from a postmenopausal woman. Observe the large amounts of electrontranslucent vesicles (arrows) in its cytoplasm (16,000X).

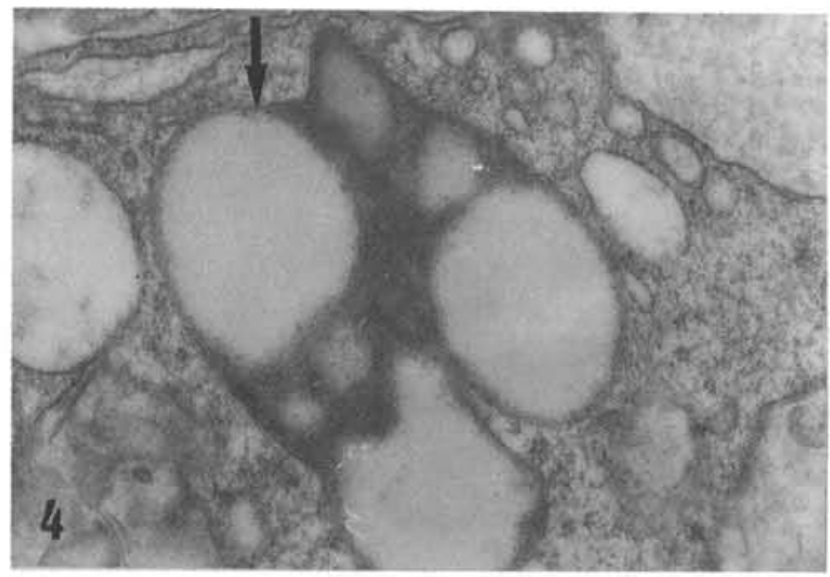

Figure 4 - Electronmicrograph with higher magnification showing the cytoplasm of a macrophage present in a corpus albicans from a postmenopausal woman. Observe electrondense bodies attached to electrontranslucent vesicles (arrow) $(30,300 \mathrm{X})$. 


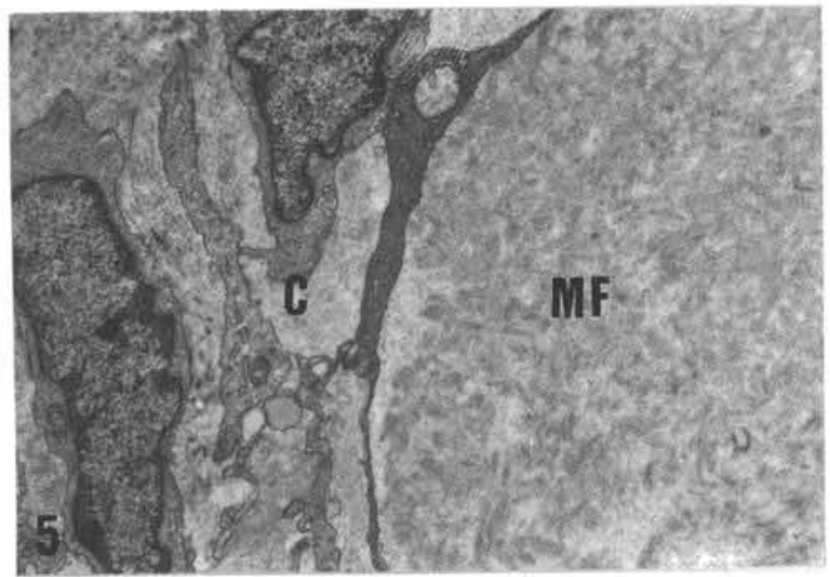

Figure 5 - Electronmicrograph showing the peripheral region of the corpus albicans. Note the presence of flaky material (FM) in the inner portion, and a great quantity of cells $(C)$ in its surroundings $(1,700 \mathrm{X})$.

with irregular cytoplasm containing electrontranslucent vesicles (Fig. 3) and small electrondense areas (Fig. 4) were observed. The peripheral region of the corpora albicantia showed large quantities of cells (Fig. 5), such as fibroblasts, macrophages and some leucocytes and plasmocytes. Some of the fibroblasts located in the peripheral region contained cytoplasmic myofilaments, characterizing the myofibroblasts (Fig. 6). We also noted the outline of a capsular structure enveloping the corpora albicantia, containing cells with pyknotic fusiform nuclei in its inner portion.

\section{DISCUSSION}

It has been reported that before menopause the corpora albicantia undergoes rapid remodeling changes and is replaced with connective tissue. However, this remodeling process might be altered after menopause, since these structures remain in the ovarian stroma for many years. ${ }^{1.25 .6}$ Our findings indicate the occurrence of a remodeling activity in the corpora albicantia during early menopause, verified by the presence of typical macrophages with signs of intense phagocytic activity in the peripheral region of these structures. In this region, fibroblasts presenting filaments in their cytoplasm can also be found. These cells, called myofibroblasts, have a contractile function and appear at sites of tissue retraction. ${ }^{7-9}$ Inside the corpora albicantia we observed fibroblasts showing cellular junctions. This feature has been described in fibroblasts in culture and in the

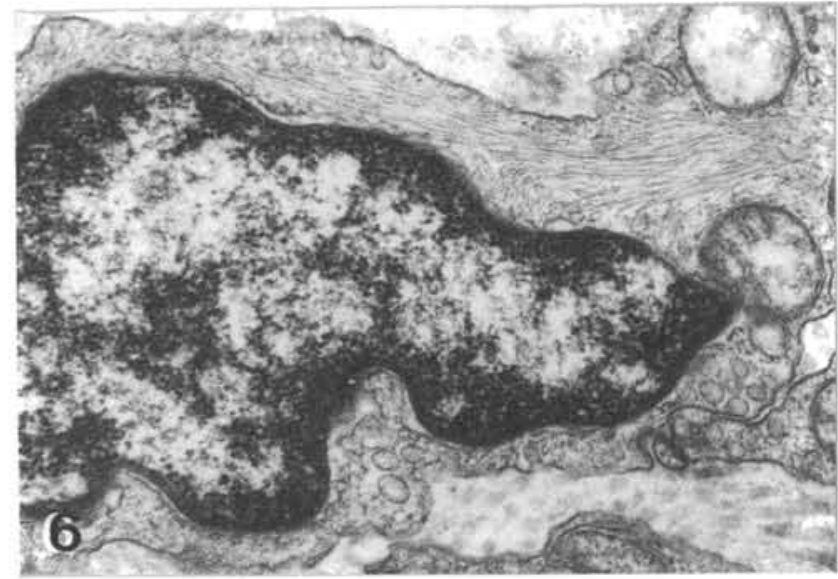

Figure 6 - Electronmicrograph of a myofibroblast located in the peripheral region of the corpus albicans from a postmenopausal woman $(21,100 \mathrm{X})$.

endometrium, but had not been reported previously in the ovary. ${ }^{3.10}$ SILVA \& GILULA ${ }^{11}$ reported that these junctions are of the gap type, and play an important role in the transmission of several stimuli from one cell to another; the cells (fibroblasts) may behave like a syncytial structure.

By comparing our results with literature data, we believe that the corpora albicantia might stimulate the proliferation of cells in their surroundings forming a fibrous capsule. Macrophages may be involved in the phagocytosis of the flaky material that arises from the degeneration of the lutheinic cells, while myofibroblasts may be responsible for the retraction of the site of the corpus albicans. The macrophages may also form channels inside the flaky material, through which an invasion of capillaries and cells could occur. These cells maintain contact with each other through gap junctions, and may start the synthesis of collagen fibers. In this manner, the hyaline material may be replaced with connective tissue.

The corpora albicantia constitutes a histological finding in ovaries of postmenopausal women. The presence of the corpora albicantia could be explained by the lower hormonal levels during this period of a woman's life, ${ }^{12}$ which probably contribute to the reduction of its remodeling process.

\section{CONCLUSION}

Our findings suggest evidence of a remodeling process of the corpora albicantia occurring during the early postmenopausal period, and probably depend upon a residual hormonal action. 


\section{Resumo}

Os autores analisam a ultra-estrutura dos ovários de dez pacientes na pós menopausa recente submetidas a ooforectomia devido a doenças ginecológicas benignas e descrevem o processo de remodelação do corpo albicante, ou seja, de sua substituição por tecido conjuntivo. Referem que tal processo depende basicamente da atividade de três tipos de células: os fibroblastos, que estariam envolvidos com a síntese das fibras colágenas; os macrófagos, que fagocitariam o material floculento presente nos corpos albicantes, e os miofibroblastos, localizados principalmente na região periférica dos corpos albicantes, e que estariam relacionados com a retraçāo do sítio remodelatório do corpo albicante. Referem ainda que o processo de remodelação dos corpos albicantes do ovário depende dos niveis hormonais vigentes.

\section{REFERENCES}

1. Joel RV, Foraker AG. The fate of the corpus albicans: a quantitative approach. Am J Obst Gynec 1959;78:1272-4.

2. Joe RV, Foraker, AG. Fate of the corpus albicans: A morphologic approach. Am J Obst Gynec 1960;80:314-6.

3. Haidar MH. Aspectos morfológicos das gônadas de mulheres com insuficiência ovariana prematura. São Paulo, 1991. (Doctoral Thesis, Escola Paulista de Medicina).

4. Focchi GRA, Simões MJ, Baracat EC, Rodrigues De Lima G. Aspectos morfológicos do corpo albicante consoante o tempo de menopausa. Anais do XVI Congresso Brasileiro de Anatomia e VIII Congresso Luso Brasileiro de Anatomia, São Paulo, SP, Brasil, 1993 (número 206).

5. Clemen PB. Anatomy and histology of the ovary. In: Blaustein SA, ed. Pathology of the female genital tract, 3rd ed. New York: Springer-Verlag, 1987:438-70.

6. Lang WR, Aponte GE. Gross and microscopic anatomy of the aged female reproductive organs. Clin Obstet Gynecol 1967;10:454-65.
7. Gabbiani G, Ryan GB, Majno, G. Presence of modified fibroblasts in granulation tissue and their possible role in wound contractions. Experientia 1971;27: 549-50.

8. Majno G. The story of the myofibroblast. Am J Surg Pathol 1979;3:535-42.

9. Ryan GB, Cliff WG, Irlé C, Montandon D, Statkov PR, Majno G. Myofibroblasts in human granulation tissue. Hum Pathol 1974;5:55-67.

10. Baracat EC. Aspectos morfológicos e morfométricos do endométrio humano na pós-menopausa, antes e após estrogenioterapia oral e transdérmica. São Paulo, 1991. (Doctoral Thesis, Escola Paulista de Medicina).

11. Silva P, Gilula NB. Gap junctions in normal and transformed fibroblasts in culture. Exp Cell Res 1972;71:397-401.

12. Utian WH. Overview of menopause. Am J Obstet Gynecol $1987 ; 156: 1280-3$ 